\title{
Convergence through Regionalization
}

\author{
Mihaela NECULITA ${ }^{\star}$, Daniela Ancuta SARPE ${ }^{\star \star}$
}

\begin{tabular}{l}
\hline \multicolumn{1}{c}{ A R T I C L E I N F O } \\
\hline Article history: \\
Accepted March 2018 \\
Available online April 2019 \\
\hline JEL Classification \\
F15, F02 \\
Keywords: \\
Integration, Cohesion policy, \\
Convergence, European funds
\end{tabular}

The EU Cohesion Policy supports sectoral and regional investments in the economic development process and this is a significant factor in helping poor regions to go to the European Single Market and to catch up with more developed regions. The European development model is an inhomogeneous one since the social and economic differences continue to be revealing, even on the increase following the last enlargements.

Among the main objectives of the European Union, it is also included the supporting of balanced and sustainable, economic and social progress, by strengthening the economic and social cohesion of the member countries, in this process being given an important role to the regions. Increasing the regions role in the European development was a phenomenon of mark of the last three decades, appreciated as an essential element of the European construction in the 21st century.

The starting point of regionalization is the regional imbalances, namely their awareness. This awareness is succeeded by the intervention of national government structures or supranational entities with the aim of regional decentralization of activities or competences that have been previously at central level. As shown in the European contemporary political map, regionalization is coming to the front both nationally and internationally. Regionalization of the states is now seen as an element of integration(Neculita 2014), by establishing a community-to-region relationship with the purpose to correct or prevent regional imbalances, by giving legitimacy to regions and institutions representing their interests. This process is conceived as a factor of democratization and exploitation of cultural distinctiveness. Expansion of the regional policy towards a cohesion policy and its reform is a way of moderating and balancing the effects of the internal market achievement, which will involve a market forces liberalization. Besides, a country wishing to become a member of the European Union must integrate into the European spirit and realities, develop a coherent and active regional policy and, at the same time, preparing its territory in order to comply with the requirements imposed by the Union. Integrating into the European Union is deemed a foreground objective, therefore the experience gained over time by these countries needs to be exploited accordingly, so that they are prepared for the changes that will take place.

\section{Literature review}

Starting with the late 1980s of the 20th century, the European system has changed, under the impact of two processes, on the one hand contradictory, and on the other hand which have mutually supported each other. The integration and fragmentation processes are those that have put to the issue the stance of states as unique, distinct actors at international level. Through the changes they have caused, these processes have lead to a growing importance of the regions along with the importance acquired by the civil society bodies to the detriment of states at international level. Over the last time, as a consequence of the higher importance of the regions, there is more awareness of a "Europe of the regions", being insisted on the fact that the region is

\footnotetext{
^, ^`Dunarea de Jos University of Galati, Romania. E-mail address: neculitam@yahoo.fr (Corresponding author)
} 
more than a simple intermediate level between the state level and the local authorities, coming to be, together with states and localities, the third point of the triangle in which the process of European integration develops (Dacian 2007).

The Community Charter on Regionalization adopted by the European Parliament in 1998 defines the region as "a territory that forms, in geographical terms, a net unity or a similar entirety of territories where there is continuity, where the population has certain common elements and which wishes to preserve its specificity thus resulted and to develop it in order to give impetus to the cultural, social and economic process (Gerard 2000). By common elements of a concrete population is understood a common specificity in terms of language, culture, historical tradition and interests related to economy and transport. A region is the "administrative-territorial unit immediately below the state level (unitary, federal, etc.) which has an elected authority of the public administration and financial means to support this authority" (the Council of Europe's sense). The European Union considers the region to be the "unit immediately below the position of the State", this unit manages, at administrative and political level, a territorial community (the European Union's sense). The regions have a huge representation at European level. They have the opportunity to access various resources and to follow their interests, taking into account that the state fails to accomplish all its missions and meet all the needs. The regional phenomenon development at European level is achieved on two levels (where the relations among the regions and with the European bodies were officialized in 1975)) :

$>$ at vertical level, between the regions and the main European institutions represented by the European Union and the Council of Europe;

$>$ at horizontal level, among the European regions.

Regionalization was born as a result of historical realities built along the way due to different causes, as well as for the purpose of settling conflicts born or deepened through an exceeding centralization of administration, fighting bureaucracy and corruption, decreasing the distance between decision makers and those whose interests need to be rightly understood and properly treated (Pacesila 2004). Gerard Marcou defines regionalization as "the process through which it is carried out the establishment of an autonomous capacity for action, having the goal of promoting a territory, at infranational or supralocal territory, by mobilizing its economic mechanism and, where appropriate, local or regional solidarity springs, as well as the development of its potential". This process can be accomplished either through pre-existing institutions or through a new territorial division intended to better meet objectives. Nevertheless, this process is always conditioned by the constraints exercised by the political and institutional framework, whose evolution can be governed by a series of tendencies (Pacesila 2004). Regionalization is a long-term process, the state introducing a second level of government in the territorial organization of a state where new institutions differentiate according to the responsibilities and authorities created, these being always superimposed to the existing local institutions.

If we think of European states, the term region, as well as regionalization cover very different political and administrative realities, from the legal status point of view.

Thus, regionalization can be (Marcou 2000):

$\checkmark$ administrative regionalization

$\checkmark$ regionalization through local communities

$\checkmark$ regional decentralization

$\checkmark$ political regionalization or regional autonomy (institutional regionalism)

$\checkmark$ regionalization through federal authorities

Regionalization is not always homogeneous, so that a state can simultaneously have, throughout its territory, several forms of regionalization of those existing, depending on the problems to be answered and the particularities it must take into account. An example may be the United Kingdom, where today there are no less than three distinct forms of regionalization.

In France there was an administrative regionalization before the introduction of current regional decentralization. Many countries in the Central and Eastern Europe have a similar evolution. On the other hand, the forms that regionalization may take in a state depend not only on socio-economic issues but also on a number of other factors, specific to each country, such as: notion of state (of the political elites and society), political circumstances and the degree of national integration. Regionalization implies risks and limits that differ from one country to another and can be appreciated differently.

It can be argued that administrative regionalization is the empowerment by the state of authorities subordinated to the government or bodies that are formed at a local level where their actions are supervised by the state, even if they have a certain legal autonomy; through the attributions and functions they possess, these have the purpose of promoting regional economic development, in the end relying on the mobilization of local communities and economic organizations.

The second type of regionalization, regionalization based on the cooperation among local communities, takes shape through the existing local collectivities, which have extensive duties and a wide field of action, which can thus enable them to reach the objectives and cooperation within a broader framework. Regionalization of this type differs from the administrative type in that the former is achieved through decentralized institutions acting within its own power framework. 
Within the framework of regional decentralization, it is insisted is on setting up a new territorial collectivity at a level higher than the level of the existing territorial collectivities, where the newly created being considered a region. The region obtains a specific constitutional expression, being characterized by the application of the general regime of territorial collectivities(Constantin 2007). It forms a new category of territorial collectivities, having yet a legal nature identical to that of the existing territorial collectivities, but being distinguished by a wider division and their competences, through which it is pursued the economic development. Although this form of regionalization changes the territorial organization, this does not prevent it from being part of the constitutional order of the unitary state.

Another type is political regionalization or regional autonomy (institutional regionalism). This form of regionalization occurs in extremely different forms only in a few countries of the European Union. The type of political regionalization is defined, in comparison with regional decentralization, through assigning the legislative power to a regional assembly, having complex competencies, whose content is characterized and guaranteed by the Constitution or a text of a constitutional nature, and for the implementation of competencies is designated an executive, having the characteristics of a regional government. In contrast with regional decentralization, political regionalization affects the state structure and changes its Constitution. Political regionalization differs from the federal state depending on several aspects, such as: the regions are not states, the composition remaining that of the unitary state; this type of regionalization is not characterized by a dual constitutive power, so the regions are "kings" by statute, subject to the vote in the national parliament, but without a constitution such as those in the federal state. The region does not participate in the exercise of national legislative power through its own representation, even though there is a multitude of forms of institutional cooperation among the state and the regions. Usually, the judicial power is unique, being organized by the central state. In addition, if federalism implies equality of rights of Member States, political regionalization is characterized by the asymmetry of institutions and competences. This form of regionalization can affect, in some states, only part of the territory, while in other states it can have consequences on the entire territory.

Regionalization through federal authorities provides the obstacle encountered in understanding the relations of the federal states with regionalization, that is, perceiving it through a multitude of false ideas. It is often considered as opposed to the nation-state, as it can allow the conciliation of that union, but having in view observance of the peculiarities. The federal state is often considered as the type of state characterized by an enhanced decentralization and functioning on the principle of guaranteeing the autonomy of its constituent units. Federalism has wide relations with regionalism and regionalization. As a first aspect, the federal state does not oppose the nation-state, in some historical contexts it is a way of national integration. We can not give an example of any national state that federalism has protected from the tensions that touch its existence, as they do not exist. Like any other type of stat, the federal state can also be affected by regionalism or regionalization, since federal states are born of a union of states, actually representing political entities and presenting themselves a number of regional and ethnic peculiarities. Thus, as observed, federalism is not the institutional expression of regionalism or regionalization. However, the federal state is also not kept out of regionalist pressures, being often subject to the regionalization trend.

\section{Convergence through the Regional Development Policy of the European Union}

Regional development policy means a set of measures and conventions that can be adopted by governments for the socio-economic development of disadvantaged regions. Over time, the instruments and objectives specific to this policy have had many evolutions and changes. Regional development is a process that involves both productive and efficient institutions, as well as a strong collaboration among public authorities, social groups at all levels and economic agents. The regional economic policy (Profiroiu 2003) includes all the forms of public interventions that take place for the geographical placement of economic activity, and it also tries to freely correct market economy for the purpose of achieving two broad interdependent objectives: economic growth and an improved social distribution. The European regional development policy relies on the following principles: the political principle, according to which wealthier countries and regions have to help the poorer, and the economic principle, according to which low levels of production in the Member States and the less-favored regions or in those with a high unemployment rate, represent a significant loss of potential and opportunity for the entire European Union. The main purpose of this policy is to turn problems into opportunities, and success relies mainly on partnerships within the European Union as well as on planning and a good governance.

The European Union regional policy is also called Cohesion Policy, a policy that intends to visibly improve the economic welfare of the regions of the European Union and to avoid as far as possible regional disparities, and it is behind thousands of projects that took place across Europe(Pascariu 2005). About more than one third of the European Union's budget is committed to this policy, which refers to ruling out the economic, social and territorial disparities in the European Union, the restructuring of declining industrial areas, as well as the diversification of rural areas with agriculture being in decline. Thus, this policy plays a significant role in wider challenges for the future, including climate change, energy supply and globalization. This also covers all European regions, regardless of the categories they belong to and according to their 
economic situation. It is intended, in the framework of territorial cohesion, to be strengthened the European regions, to be promoted territorial integration and to bring coherence to the European Union policies in order to be able to contribute to sustainable development, as well as to the global competitiveness of the European Union. A more precise definition of sustainable development is that it can meet the needs of the present without damaging the capacity of future generations to satisfy their own needs. The major objective of the territorial cohesion policy is to contribute to a balanced allocation of economic and social resources among the European regions, with priority in the territorial dimension. In other words, resources and opportunities must be shared equally among the regions and their populations. Alternatively, it is necessary an integrated approach to other EU policies in order to be able to reach this primary objective.

The regional policy of the European Union is based on the following two criteria:

$\checkmark$ Efficiency - whereby, in certain regions, the concentration of some specific economic activities, of the production of certain goods, etc. can prevent efficient allocation of resources, thus diminishing the effects of global welfare;

$>$ Equity - appears in the form of an act of solidarity of the developed regions to the less developped ones, through the fact that there is a fair allocation among regions and social categories as a result of the welfare effects.

Currently, the policy objectives are: to promote European territorial cooperation for the purpose of curtailing the economic significance of national borders, to promote economic convergence in order to help disadvantaged regions represented predominantly by the new Member States to get closer to the more prosperous countries, to apply different measures intended to promote regional competitiveness and regional employment. For the Convergence objective, the following examples of financed projects can be found: improving basic infrastructure, supporting enterprises, building or bringing up-to-date waste and water treatment facilities, and ultimately improving access to high-speed internet connections.

The regions have been classified and divided into three groups:

* Less developed regions, where GDP/capita is less than $75 \%$ of the EU average

* Transition regions, where GDP/capita is between $75 \%-90 \%$ of the EU average

* Developed regions, where GDP/capita is higher than $90 \%$ of the EU average

Areas within the European Union considered less developed:

$\checkmark$ Bulgaria - within it all areas are designated as disadvantaged, except the Southeastern region

$\checkmark$ Croatia - the whole country

$\checkmark$ Estonia - the whole country

$\checkmark$ France - French Guyana, Guadeloupe, Martinique, Réunion

$\checkmark$ Greece- Anatoliki Makedonia Thraki, Dytiki Ellada, Ipeiros, Kentriki Makedonia, Thessalia

$\checkmark$ Italy - Basillicata, Calabria, Campania, Apulia, Sicily

$\checkmark \quad$ Latvia - the whole country

$\checkmark$ Lithuania - the whole country

$\checkmark$ United Kingdom - Cornwall and the Scilly Islands, West Wales and Valleys

$\checkmark$ Poland - the whole country except the Masovian Voivodeship

$\checkmark$ Portugal-Alentejo, Azores, Centro Norte

$\checkmark$ Czech Republic - except Prague

$\checkmark$ Romania-Bucharest is the exception

$\checkmark$ Slovakia - the whole country except Bratislava

$\checkmark$ Slovenia- Vzhodna Slovenija

$\checkmark$ Spain - Extremadura

$\checkmark$ Hungary - except Central Hungary

The highest amount of funding for the regional development policy is allocated to less developed regions and covers the poorest areas in Europe, with their GDP/capita having a weight less than $75 \%$ of the EU average. In this category come all the regions of the new Member States, the most numerous being those in southern Italy, Greece and Portugal, but also in some parts of the United Kingdom and Spain.

The regions within the European Union termed as the most developed are the following:

$\checkmark$ Austria- except Burgenland

$\checkmark$ Belgium - Flanders, Brabant Wallon

$\checkmark$ Cyprus

$\checkmark$ Denmark - except for Sjaelland

$\checkmark$ Finland

$\checkmark$ France - Aquitaine, Burgundy, Brittany, Center, Champagne-Ardenne, Île-de-France, Midi-Pyrénées, Pays de la Loire, Provence-Alpes-Côte d'Azur, Rhône-Alpes, Upper Normandy

$\checkmark$ Germany - Berlin, Leipzing, all former West Germany except Lüneburg

$\checkmark$ Greece - Attiki, Notio Aigaio 
$\checkmark \quad$ Italy - Emilia-Romagna, Friuli-Venezia Giulia, Lazio, Liguria, Lombardy, Marche, Piedmont, South Tyrol, Trentino, Tuscany, Umbria, Valle d'Aosta, Veneto

$\checkmark$ Luxembourg

$\checkmark$ United Kingdom

$\checkmark$ Netherlands

$\checkmark$ Poland - Masovian Voivodeship

$\checkmark$ Portugal, the region of Lisbon, Madeira

$\checkmark$ Czech Republic - Prague

$\checkmark$ Romania - Bucharest

$\checkmark$ Slovakia - Bratislava

$\checkmark$ Slovenia - Zahodna Slovenija

$\checkmark$ Spain - Balearic Islands, Aragon, Basque Country, Asturias, Cantabria, Catalonia, Castilla y León, Ceuta, Galicia, La Rioja, Madrid Region, Valencian Community, Navarra

$\checkmark$ Sweden

$\checkmark$ the Hungary Közép-Magyarország

These regions with a favorable economic situation have a GDP/capita above $90 \%$ of the European Union average. These areas are being funded as it is intended to be created new jobs by transforming the regions in question, in a more attractive way for enterprises and investors. Among the possible projects are the development of transport, the support of research centers, universities, small businesses and new enterprises.

\section{The structure of the EU budget 2014-2020}

Fig. 1 The European Commission proposal on the multiannual financial framework 2014-2020

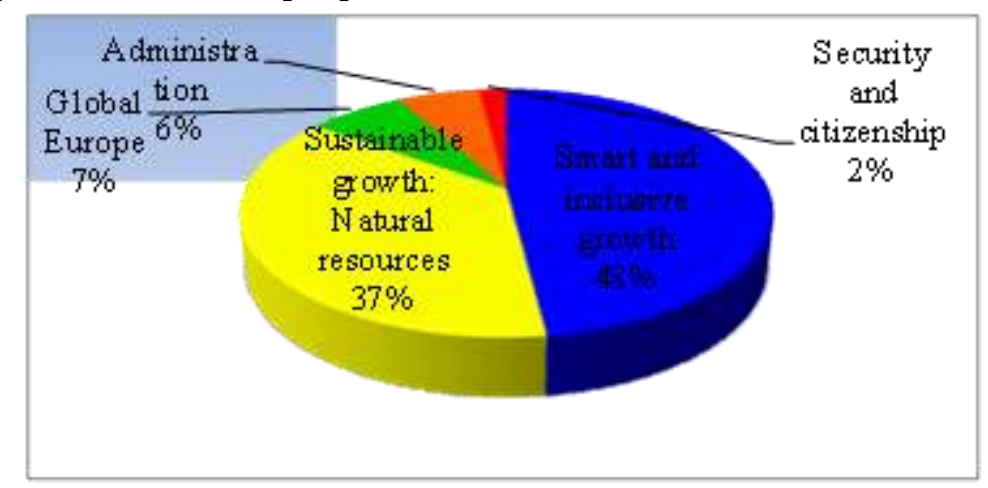

Source:http://ec.europa.eu, accessed on 12.05.2018

The European budget for the current cycle was negotiated, the financial framework for the period 2014-2020 being divided as follows:

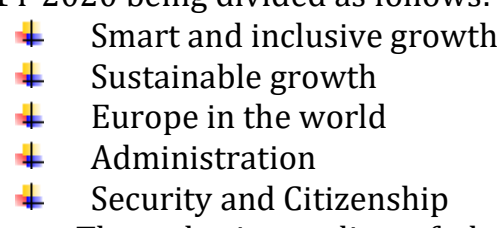

The cohesion policy of the European Union, a policy that ensures the European convergence financing, is established based on seven-year programming periods, so the current period covers the 20142020 period. There have been allocated $€ 356$ billion for measures in the EU Member States, the equivalent to almost one-third of the total EU budget of 32.5\%. A legislative package for the 2014-2020 cohesion policy was adopted on 17 December 2013 and it included a common regulation concerning provisions (CPR) laying down general provisions and simplification of the European structural and investment funds (ESI); CPR was modified in October 2015 in order to take into account Greece's unique situation resulting from the financial crisis and the global economy. There have been a number of changes as regards the drafting and implementation of cohesion policy for the 2014-2020 programming period, with a change in funding in order to allocate more funding to the European Commission's priorities, including research and innovation, support for small businesses, social inclusion, digital and broadband technologies, energy, water, the environment, climate change, sustainable transport and a low-carbon economy.

For the 2014-2020 period, the rules concerning cohesion policy financing have been simplified, so that a harmonized set of rules is now being applied to all funds. The policy has been adopted so as to be based 
on a results-oriented approach, through more transparent controls, decreasing bureaucracy, introducing specific preliminary conditions before the funds are released and introducing measurable objectives for a better accountability. The EU cohesion policy is in close connection to the 2020 strategy and the Union's investment plan. In the 2014-2020 period, the programming of cohesion policy is, for the first time, incorporated into the overall economic policy coordination, in particular the European Semester, a regular cycle of economic policy coordination, intended to guide the individual efforts of the EU Member States, thus leading to the desired impact on their growth. The relation between cohesion policy and economic reforms is such that the European Commission can suspend regional funding for any Member State which fails to comply with the EU economic rules. Another change for the 2014-2020 period is a more important role given to the urban dimension of the regional policy, especially concerning the measures meant to contribute to the fight against social exclusion. Taking this into account, a minimum amount from the ERDF has been allocated for city-integrated projects and the ESF to support marginalized communities.

There is a single set of rules covering the five EU structural and investment funds, that is, ESI funds. The purpose of these rules is to establish a clear link with the Europe 2020 strategy and generate smart, sustainable and inclusive growth in the EU, to improve coordination, ensure a coherent implementation and make access to ESI funds as directly as possible for those who can benefit from them. The 2014-2020 programming period presented a new legislative framework for these five funds, which fall under the EU Cohesion Policy, the Common Agricultural Policy and the Common Fisheries Policy. These five ESI funds are the following: the European Regional Development Fund, the European Social Fund, the Cohesion Fund, the European Agricultural Fund for Rural Development, European Fund for Fisheries and Maritime Affairs.

Tab. 1 Allocation of the Cohesion Policy funds for the 2014-2020 programming period

\begin{tabular}{|c|c|c|c|c|c|c|}
\hline \multirow[b]{2}{*}{$\begin{array}{l}\text { Millions of } \\
\text { Euros }\end{array}$} & \multicolumn{3}{|c|}{ ERDF and ESF } & \multirow[b]{2}{*}{$\begin{array}{l}\text { Cohesion } \\
\text { Fund }\end{array}$} & \multicolumn{2}{|c|}{ Cohesion Policy - Total } \\
\hline & $\begin{array}{c}\text { Less } \\
\text { Developed } \\
\text { regions }\end{array}$ & $\begin{array}{c}\text { Transition } \\
\text { Regions }\end{array}$ & $\begin{array}{c}\text { Developed } \\
\text { Regions }\end{array}$ & & Value & $\begin{array}{c}\text { EU } \\
\text { Weight } \\
\%\end{array}$ \\
\hline UE-28 & 181289.8 & 37984.5 & 57428.8 & 63282.6 & 356450.1 & 100.0 \\
\hline Austria & - & 72.3 & 906 & - & 1235.6 & 0.3 \\
\hline Belgium & - & 1039.7 & 949.6 & - & 22294.9 & 0.6 \\
\hline Bulgaria & 5089.3 & - & - & 2278.3 & 7588.4 & 2.1 \\
\hline Cyprus & - & - & 432.3 & 294.9 & 771.5 & 0.2 \\
\hline Croatia & 5837.5 & - & - & 2509.8 & 8559.6 & 2.4 \\
\hline Denmark & - & 87.3 & 332.3 & - & 559.8 & 0.2 \\
\hline Estonia & 2437.7 & - & - & 1061.5 & 3554.6 & 1.0 \\
\hline Finland & - & - & 1004.9 & - & 1471.6 & 0.4 \\
\hline France & 3434.3 & 4253.3 & 6322.0 & - & 15878.2 & 4.5 \\
\hline Germany & - & 9771.5 & 8498 & - & 19234.9 & 5.4 \\
\hline Greece & 7345.7 & 2922.1 & 2.511 & 3265.7 & 16447.6 & 4.6 \\
\hline Ireland & - & - & 955.3 & - & 1192.2 & 0.3 \\
\hline Italy & 23546.5 & 1505 & 7712.5 & - & 34468.2 & 9.7 \\
\hline Latvia & 3039.8 & - & - & 1349.4 & 4511.8 & 1.3 \\
\hline Lithuania & 4628.7 & - & - & 2048.9 & 6823.1 & 1.9 \\
\hline Luxembourg & - & - & 39.6 & - & 59.7 & 0.0 \\
\hline Malta & - & 490.2 & - & 217.7 & 725 & 0.2 \\
\hline Poland & 49628.7 & - & 3777.3 & 23208 & 77.567 & 21.8 \\
\hline Portugal & 16642.2 & 324.6 & 1237.5 & 2861.7 & 21471.1 & 6.0 \\
\hline $\begin{array}{l}\text { United } \\
\text { Kingdom }\end{array}$ & 2641 & 2590.6 & 5594.6 & - & 11897.9 & 3.3 \\
\hline
\end{tabular}




\begin{tabular}{|c|c|c|c|c|c|c|}
\hline \multirow[b]{2}{*}{$\begin{array}{l}\text { Millions of } \\
\text { Euros }\end{array}$} & \multicolumn{3}{|c|}{ ERDF and ESF } & \multirow[b]{2}{*}{$\begin{array}{l}\text { Cohesion } \\
\text { Fund }\end{array}$} & \multicolumn{2}{|c|}{ Cohesion Policy - Total } \\
\hline & $\begin{array}{l}\text { Less } \\
\text { Developed } \\
\text { regions }\end{array}$ & $\begin{array}{c}\text { Transition } \\
\text { Regions }\end{array}$ & $\begin{array}{l}\text { Developed } \\
\text { Regions }\end{array}$ & & Value & $\begin{array}{c}\text { EU } \\
\text { Weight } \\
\%\end{array}$ \\
\hline Czech Republic & 14824 & - & 546.7 & 6143.9 & 21867.9 & 6.1 \\
\hline Romania & 14607 & - & 893 & 6935 & 22993.8 & 6.5 \\
\hline Slovakia & 9130.3 & - & 328.7 & 4168.3 & 13922.8 & 3.9 \\
\hline Slovenia & 1296.1 & - & 848.6 & 914 & 3130.8 & 0.9 \\
\hline Spain & 2155.6 & 14927.9 & 11562.6 & - & 30716.7 & 8.6 \\
\hline Sweden & - & - & 1.491 .9 & - & 2085.3 & 0.6 \\
\hline Netherlands & - & - & 1.020 .6 & - & 1410.2 & 0.4 \\
\hline Hungary & 15005.2 & - & 463.7 & 6025.4 & 21905.9 & 6.1 \\
\hline
\end{tabular}

Source: European Commission, Directorate-General for Regional and Urban Policy

The above table gives an overview of the Cohesion Policy funds allocation (for the two Structural Funds and the Cohesion Fund) for the 2014-2020 programming period. During this time, Poland received an allocation of $21.8 \%$ of the total EU funds for the Cohesion Policy. The following highest allocations are for Italy (9.7\%) and Spain (8.6\%), while Portugal, the Czech Republic, Hungary and Romania should receive between $6.0 \%$ and $6.5 \%$ of the total funding of cohesion policy during the programming period.

\section{Conclusions}

The convergence theory has not been confirmed by the European integration process, so even though there has been a decrease in the gaps among member countries, the pace of convergence has been slow, and in the event of a widening of gaps between regions, the convergence effects correlated with those of divergence. So that, the Europeans have adjusted their integration strategy to the notion of divergence, as a result of the effects during the preparations for the changeover to the single currency and the integration crises.

The European Union has its own model that dreams of achieving economic growth by narrowing disparities and by integrating the economies of all member countries. But, like any model, it can not only have strengths but also weaknesses, such as the fact that some policies are adapted for rich states and can not have the same potential in the case of the new least developed countries, so the performance of the member countries leading to economic growth is stimulated by the economic equilibrium.

The European integration produces different changes at both macro and micro-economic level and has quite significant consequences for a multitude of economic indicators in the member countries. But as any process, it can not have only positive aspects, thus we also find negative effects within it, where the new Member States have the obligation to ensure a living standard compared to the previous one in the old EU states, which have an enhanced labor productivity, a fairly high GDP/capita, as well as high labor costs. The European Union has to reduce unemployment and poverty in all member countries through various specific methods, to overcome the current economic crisis, and for Europe to succeed, all European, national, regional and local actors need to know and perform their role well. If the cohesion policy has a decisive role, it can ensure a sustainable growth by promoting the development of the European Union and the regions, all these being possible through a reduction of regional disparities.

Within the EU, there is a process of transferring the various components of the central power to the regional or local level, which occurrs especially in countries that have had in the past a high degree of centralization of the decisions, as well as the actions at central level. Regionalization and decentralization are instruments for making more efficient the allocation, as well as the spending of available resources, which can govern the emergence of regional advantages, remove existing disparities and ensure a sustainable process of economic and social cohesion. Regionalization in the EU highlights the manner in which the peculiarities of power attribution go together with territory elements of the state, as well as with its historical tradition and evolution.

Attracting and incorporating European funds leads to an increase in consumption, the economy as a whole and trade. It is worth mentioning that there has been lately a growing debate on the European funds absorption, but particularly on the attracted percentage, however the issue is not about the attracted amount, but about the way in which we manage this percentage and how we allocate these funds depending on the specific needs of each individual EU country and citizens. 
Attracting European funds certainly leads to a higher convergence, growing the GDP per capita. During 2014-2020, the European Union has directed a large share of funding towards research. Throughout the three sessions, European funds have propelled national and international investment, resulting in an increase in jobs, incomes and consumption, these effects being more or less visible in less developed regions.

\section{References}

1. Constantin, D.L. și Dimian G. C.(2007). Competitivitatea regiunilor din România în contextual integrării în Uniunea Europeană, Jurnalul Economic, nr.24

2. Dacian Cosmin Dragoș(2007), Uniunea Europeană, Editura C.H.Beck, București

3. Gabriela Carmen Pascariu (2005), Despre convergență și divergență în procesul de integrare europeană

4. Gerard Marcou-,_Régionalisation en Europe”,Parlament Européen(2000),L-2929 Luxembourg, pg.9-34

5. Marius Profiroiu, Irina Popescu(2003), Politici europene, Editura Economică, București

6. Neculiță Mihaela, Neculiță Valentin(2014), Integrarea Regională și Fondurile Europene în Țările din Europa Centrală și de Est, Editura Didactică și Pedagogică

7. Mihaela Pacesila(2004), Regionalizarea în statele Uniunii Europene.Administrație și management public 3/2004,pag.104

8. Uniunea Europeană. Regiuni în dezvoltare, Europa în dezvoltare-Al patrulea raport privind coeziunea economică și socială, ISBN 9779-05717-5

9. Comisia Europeană. Politica regioală. Să înțelegem politicile Uniunii Europene(2014), ISBN 978-92-79-41303-2

10. *** European Commission -budget-2014-2020

11. *** European Commission, Directorate-General for Regional and Urban Policy

12. ***http://ec.europa.eu

13. ***https://europa.eu/european-union/topics/regional-policy_ro

14. ***https://ro.wikipedia.org/wiki/Integrare_european $\%$ C4\%83 